\title{
Articles
}

\section{THE WELFARE STATE AND ECONOMIC GROWTH}

\author{
Vratislav Izák*
}

\begin{abstract}
:
The paper examines whether redistribution policy is bad or good for economic growth by analysing government expenditure on the welfare state in the old and new post-socialist EU countries from the mid-1990 to 2008. Due to the differences among countries fixed effect is included in the model using panel data. We find negative association between the mean values of expenditure on the welfare state in several time periods and the subsequent GDP growth rate for EU-25 and also for the subsets (EU-15 and EU-10) of the EU countries. When taking into account explicitly the government budget constraint and applying dynamics the same conclusion can be drawn for EU-25. Welfare state expenditure has statistically significant negative coefficient confirming the postulated hypothesis of a negative impact on the GDP growth rate.
\end{abstract}

Keywords: government expenditure, welfare state, economic growth, panel fixed effects

JEL Classification: E6, H5

\section{Introduction}

The welfare state exists to a certain degree in all Member States of the European Union. The theoretical arguments support the existence of different forms of the welfare state not only for well-known equity reasons but also in efficiency terms.

The term "welfare state" is used in this paper (Barr, 2004) as a shorthand for the state's activities in four broad areas: cash benefits, health care, education and housing. In broad terms the contemporary welfare state comprises cash benefits and benefits in kind.

* University of Economics Prague, Department of Public Finance, Czech Republic (izak@vse.cz). This paper was written with the support of the Grant Agency of the Czech Republic No.402/09/0283 and IGA VŠE F1/20/2010. 
The demographic development in Europe will question the long-term sustainability of public finances in the EU (putting aside the current fiscal problems thanks to financial and economic crisis). The assessment carried out regularly by the European Commission summarises the projected change in age-related expenditure as a share of GDP over the long term. These expenditures (pensions, health care, education) represent the main bulk of spending on the welfare state. Projected changes from 2010 to 2030 and 2050 show the increase especially in Cyprus, Slovenia, Spain, Luxembourg, the Czech Republic, Hungary, Ireland and Belgium (European Economy - Public Finances in EMU, 2008, 2007). Summarizing, both the old EU countries and recently acceded Member States will face considerable sustainability gaps.

Conventional wisdom says that redistribution through cash payments and benefits in kind is growth decelerating because of negative incentive effects on economic agents. On the contrary, some authors suggest that redistribution may be good to a certain degree. In the development models (Brown, Jackson, 1994) in the developed phase of the economy there is less need for infrastructural expenditure or for the correction of market failure. Instead transfer payments (in cash or in kind) become the main items of expenditure. But once such forms of expenditure become established, they are difficult to reduce. They also increase with heightened expectations and through the effect of the above mentioned ageing population in EU Member States.

Public spending is seen as having an important role in supporting economic growth but it also is a key variable influencing the sustainability of public finance. Over the last years the importance of quality of public finance has been brought to the forefront of public debates. Enormously increasing public deficits caused by different stimulus packages raise the pressure to use resources more efficiently. From this point of view some progress has been made by looking at the composition of expenditure by functions of government (COFOG) which we utilize in this paper by measuring the extent of the welfare state.

The remainder of the paper is organized as follows. In Section 2 we summarize the most relevant literature stressing the different possible approaches. In Section 3 we present trends in expenditure on the welfare state in the Member States of the European Union. In the following section partial approach-simple correlations with mean values has been discussed. In Section 5 the attention is concentrated on the explicit use of government budget constraint-both expenditure and taxes are analysed and some conclusions are drawn. In Section 6 we discuss the conclusions and caveats.

\section{Literature Review}

The relationship between government expenditure and economic growth can be examined from different angles of approach.

In a seminal paper Tanzi and Schuknecht (1997) analyse the level of public spending in full-fledged market economies and try to find the level of spending bringing much of the potential social gain. Spending beyond that level (between 30 and 40 percent of GDP) does not contribute much. Masson (2000) examines in what areas should a European fiscal policy operate, and finds no support for the view that redistribution is favourable to growth (15 EU countries in the period 1993-98). 
Gerson (1998) stresses the role of well-targeted government expenditures on health, education and infrastructure and underlines that spending on social services to maintain the social fabric may increase growth if it contributes to political stability.

The goal of often quoted paper of Easterly and Rebelo (1993) is to provide a comprehensive summary of the statistical association between measures of fiscal policy and the rates of growth. The empirical findings (data set of about 100 countries for the period 1970-1988) are summarized by the list of ten stylized facts. Their main conclusion is that in endogenous growth models fiscal policy can be one of the main determinants of the observed differences in growth experiences.

Kocherlakota and Yi (1997) construct a simple model that nests endogenous and exogenous growth as special cases and then derive the reduced-form relationships that underlie their empirical work. Long-time series of real per capita GDP growth rate (USA 1891-1991, United Kingdom 1831-1991) and two measures of public capital and income taxes enable them to select optimal time lag ( 8 years). Their central finding is that when both the spending and the revenue variables are included in a growth regression, they obtain estimates that are inconsistent with exogenous growth and consistent with endogenous growth.

It was probably L. Helms (1985) who underscored first the importance of considering the incentives provided by expenditures as well as taxes recognizing the government budget constraint. His growth equation has an autoregressive form enabling him to calculate both the short-run and long-run effects of a change in selected fiscal variables.

Similarly Mofidi and Stone (1990) stress that economic performance is dependent not only upon taxes, but also upon the types of expenditures the taxes finance. They examine the impact of state and local taxes on net investment and employment when the revenues are devoted to transfer-payment programs.

Kneller, Bleaney and Gemell (1999) find strong support for the predictions of endogenous growth models that structure of taxation and public expenditure can affect the steady-state growth rate. They criticize the partial studies focused exclusively on one side of the budget only and stress the importance of the implicit financing assumptions originally suggested by Helms.

In the following paper the same authors Bleaney, Gemell, Kneller (2001) try to evaluate the role of fiscal policy in both neoclassical and endogenous growth models by examining the impact of various sub-divisions of expenditure and taxes on growth. The authors discuss several difficulties arising during the empirical investigations (e.g. the data limitation, the endogeneity of regressors in growth equations, the necessity to capture the long-run behaviour).

Afonso and Furceri (2008) try to answer the question if social contributions (size and volatility) have a sizeable, negative and statistically significant effect on growth in a paper analysing a set of OECD and EU countries in 1970 to 2004.

Afonso and Allegre (2008) test whether a reallocation of government spending can enhance economic growth in a set of European countries in the period 1970-2006 applying modern panel data techniques. Their theoretical model summarizes the key findings of the relationship of public expenditure with economic growth. They are able to identify the negative impact of social security contributions on economic growth. On functional expenditure the study points to a negative impact of health and social 
protection expenditures on production and the growth-enhancing behaviour of public expenditure on education.

\section{Descriptive Statistics}

Under the heading expenditure on the welfare state (WSE) we understand in the empirical analysis spending by government on 4 items at the first level (division) of COFOG classification (The international Classification of the Functions of Government. Manual on Sources and Methods of the Compilation of COFOG Statistics, Eurostat, 2007).

GF.10 Government Expenditure on Social Protection

GF.09 Government Expenditure on Education

GF.07 Government Expenditure on Health

GF.06 Government Expenditure on Housing and Community Amenities.

The functional breakdown of government expenditure is based on COFOG, which was developed by the OECD and adopted as a standard in national accounts. Eurostat collects and publishes COFOG data from European countries based on the harmonized accounting principles in the European System of Accounts 1995 (see Box 1).

Until recently COFOG data has only been available in Europe on a higher aggregated level (COFOG level I with 10 items). However, due to the focus on the quality of public finances, there is now a strong user demand for more detailed (COFOG level II) data which breaks down government expenditure into 69 different functional groups and enable more detailed analysis of WSE.

Box 1

\section{Social Expenditure in COFOG and ESA 95}

Some authors use directly data from the European System of Accounts 1995 (ESA 95) as a proxy for social expenditure because of longer time series neglecting the differences between COFOG and ESA 95.

The ESA 95 transmission programme compares categories for COFOG analysis and ESA 95 transactions (Manual on COFOG Statistics, 2007; Statistics in Focus, Economy and Finance, 2005). The programme shows the breakdown by function and transactions: the column headings refer to the ESA 95 transaction codes and the row headings to the COFOG divisions. We use data from the transmission programme (data for 2003, million euro) to compare social protection data in the COFOG classification and the social payment in ESA 95.

Table 1 discovers the measure of bias when using social protection (division 10 of COFOG) instead of a sum of some headings from ESA 95. Under social payments in ESA 95 one understands social benefits other than social transfers in kind (D.62) plus three sub-headings of social transfers in kind. 
Table 1

Significance of Social Protection (COFOG) for Social Payment (ESA 95) in EU-25 (social protection in $\%$ of social payment)

\begin{tabular}{|l|l|l|l|l|l|l|l|l|l|l|l|l|}
\hline AT & BE & DE & DK & EL & ES & FI & FR & IE & IT & LU & NL & PT \\
\hline 79.0 & 71.5 & 75.6 & 91.2 & 100 & 83.6 & 90.7 & 79.2 & 90.6 & 87.6 & 77.9 & 76.5 & 79.5 \\
\hline SE & UK & CZ & EE & LT & LV & HU & PL & SI & SK & & & \\
\cline { 1 - 9 } 86.9 & 100 & 68.5 & 82.3 & 85.1 & 96.9 & 89.2 & 99.8 & 85.1 & 97.5 & & & \\
\hline
\end{tabular}

Source: Author's calculations based on Table 3 (Statistics in Focus, 2005).

Note: Usual cross-section identifiers used in this table and in the following panel analysis are for new countries: Bulgaria (BG), Czech Republic (CZ), Estonia (EE), Hungary (HU), Lithuania (LT), Latvia (LV), Poland (PL), Romania $(\mathrm{RO})$, Slovenia (SI), Slovakia (SK). For old EU countries: Austria (AT), Belgium (BE), Germany (DE), Denmark (DK), Greece (EL), Spain (ES), Finland (FI), France (FR), Ireland (IE), Italy (IT), Luxembourg (LU), the Netherlands (NL), Portugal (PT), Sweden (SE), United Kingdom (UK).

Data for Bulgaria and Romania are missing.

In some countries, following the table, first of all in the Czech Republic, but also Germany, Denmark and the Netherlands data for social protection (COFOG) represent only about $3 / 4$ of social payment in ESA 95 according to this breakdown. These differences must be keept in mind by the researcher when using longer-time series of social payments.

The broad-brushed description of the development of WSE (as percentage of GDP) reveals the well-known fact, that the ratio of WSE is higher in the majority of EU-15 than in post-socialist newly acceded members (EU-10; see Table 2).

For 6 from 15 old EU countries (Austria, Denmark, Spain, Finland, Ireland and Sweden) the maximum level of WSE was reached in 1995 (taking into account our data set) and since then the path is downward. The exceptions are Greece, Italy and the United Kingdom with peak in 2007 (maybe it is not a chance - these countries have to cope with enormous difficulties vis-à-vis the sustainability of public finances in these months). The same can be said for Hungary (the peak in 2006) - a trouble maker among the post-socialist countries, whereas the majority of EU-10 countries exhibited the peak at the beginning of the 21 st century.

Table 2 shows WSE as a percentage of GDP to give an idea of the size of the welfare state, for its concept is significant first of all in Scandinavian countries (in Sweden peaking even at $42.6 \%$ in 1995, in Denmark 39.8\% and the same figure in Finland also in 1995) supplemented by France (37.6\% in 2004), Austria (37.4\% in 1995) and Germany (34.3\% in 2003). On the other end the lowest level has been in Ireland (maximum 24.5\% in 1995 with a downward path since this year till 2000 when again an upward path begins). In the sample of EU-10 countries only Slovenia, Hungary and Poland exhibit values comparable with those of EU-15, with Baltic countries, Romania and Bulgaria having the ratio hovering around $20 \%$ of GDP. Government WSE appears relatively stable across countries in both subsamples with outliers Portugal and Finland (high standard deviations in EU-15). 
Table 2

Welfare State Expenditure - Main Descriptive Statistics (\% of GDP)

\begin{tabular}{|l|c|c|c|c|c|c|}
\hline & Mean & Maximum & Minimum & Stand.dev. & Observations & Time period \\
\hline AT & 35.39 & 37.40 & 33.40 & 1.38 & 14 & $1995-2008$ \\
\hline BE & 30.64 & 31.40 & 29.30 & 0.63 & 14 & $1995-2008$ \\
\hline DE & 32.86 & 34.30 & 30.70 & 1.02 & 14 & $1995-2008$ \\
\hline DK & 38.36 & 39.80 & 36.80 & 0.95 & 14 & $1995-2008$ \\
\hline EL & 24.85 & 28.70 & 22.20 & 1.93 & 14 & $1995-2008$ \\
\hline ES & 24.24 & 25.70 & 23.20 & 0.82 & 14 & $1995-2008$ \\
\hline FI & 34.80 & 39.80 & 32.20 & 2.48 & 14 & $1995-2008$ \\
\hline FR & 36.86 & 37.60 & 35.70 & 0.61 & 14 & $1995-2008$ \\
\hline IE & 21.94 & 24.50 & 19.00 & 1.47 & 13 & $1995-2007$ \\
\hline IT & 29.63 & 31.20 & 28.80 & 0.72 & 14 & $1995-2008$ \\
\hline LU & 26.81 & 28.50 & 24.60 & 1.28 & 14 & $1995-2008$ \\
\hline NL & 27.65 & 29.40 & 26.00 & 0.91 & 13 & $1996-2008$ \\
\hline PT & 27.81 & 31.30 & 24.50 & 2.44 & 13 & $1995-2007$ \\
\hline SE & 38.59 & 42.60 & 35.90 & 1.89 & 14 & $1995-2008$ \\
\hline UK & 28.21 & 30.90 & 25.90 & 1.62 & 14 & $1995-2008$ \\
\hline BG & 22.20 & 23.70 & 20.00 & 1.25 & 8 & $2000-2007$ \\
\hline CZ & 25.19 & 27.20 & 23.10 & 1.38 & 14 & $1995-2008$ \\
\hline EE & 22.29 & 25.40 & 19.90 & 1.81 & 14 & $1995-2008$ \\
\hline HU & 28.24 & 30.10 & 25.60 & 1.44 & 7 & $2001-2007$ \\
\hline LT & 21.57 & 23.60 & 20.20 & 1.28 & 9 & $2000-2008$ \\
\hline LV & 21.84 & 24.60 & 20.00 & 1.15 & 13 & $1996-2008$ \\
\hline PL & 28.84 & 30.60 & 26.90 & 1.33 & 7 & $2002-2008$ \\
\hline RO & 19.58 & 21.10 & 19.00 & 0.81 & 6 & $2002-2007$ \\
\hline SL & 29.97 & 31.00 & 27.70 & 1.00 & 9 & $2000-2008$ \\
\hline SK & 23.56 & 25.90 & 20.40 & 1.50 & 14 & $1995-2008$ \\
\hline IO & & & & & & \\
\hline
\end{tabular}

Source: Author's calculations.

Disentangling WSE in Table 3 we see that the decisive item is social protection (spr) representing over $50 \%$ of WSE in the majority of countries. Quantitatively important there are also expenditure on health (hea) and education (edu), whereas expenditure on housing and community amenities are almost negligible and represent not shown residual.

The mean values of ratio of social protection on WSE are very high, as expected, in Scandinavian countries, but also in Greece and Germany. Less than half of WSE they reach in Ireland, Estonia and Romania. As concerns the impact of social protection on the rate of economic growth they are regarded practically in all relevant papers as having negative impact. 
Composition of WSE

\begin{tabular}{|l|c|c|c|c|c|c|}
\hline \multirow{2}{*}{} & \multicolumn{2}{|c|}{ spr } & \multicolumn{2}{c|}{ edu } & \multicolumn{2}{c|}{ hea } \\
\cline { 2 - 7 } & Mean & \% WSE & Mean & \% WSE & Mean & \%WE \\
\hline AT & 21.03 & 59.4 & 5.84 & 16.5 & 7.66 & 21.6 \\
\hline BE & 17.79 & 58.1 & 5.87 & 9.2 & 6.64 & 21.7 \\
\hline DE & 21.44 & 65.2 & 4.24 & 12.9 & 6.24 & 19.0 \\
\hline DK & 23.56 & 61.4 & 7.24 & 18.9 & 6.91 & 18.0 \\
\hline EL & 17.16 & 69.1 & 2.89 & 11.6 & 4.42 & 17.8 \\
\hline ES & 13.40 & 55.3 & 4.43 & 18.3 & 5.41 & 22.3 \\
\hline FI & 21.79 & 62.6 & 6.23 & 17.9 & 6.34 & 18.2 \\
\hline FR & 21.37 & 58.0 & 6.28 & 17.0 & 7.51 & 20.4 \\
\hline IE & 9.74 & 44.4 & 4.46 & 20.3 & 6.38 & 29.1 \\
\hline IT & 17.95 & 60.6 & 4.71 & 15.9 & 6.21 & 21.0 \\
\hline LU & 16.66 & 62.1 & 4.59 & 17.1 & 4.75 & 17.7 \\
\hline NL & 17.39 & 62.9 & 5.03 & 18.2 & 4.37 & 15.8 \\
\hline PT & 13.97 & 50.2 & 6.75 & 24.3 & 6.50 & 13.4 \\
\hline SE & 23.61 & 61.2 & 7.11 & 18.4 & 6.61 & 17.1 \\
\hline UK & 15.63 & 55.4 & 5.39 & 19.1 & 6.21 & 22.0 \\
\hline BG & 12.99 & 58.5 & 4.08 & 18.4 & 4.50 & 20.3 \\
\hline CZ & 13.04 & 51.8 & 4.54 & 18.0 & 6.43 & 25.5 \\
\hline EE & 10.61 & 47.6 & 6.76 & 30.3 & 4.41 & 19.8 \\
\hline HU & 16.24 & 57.5 & 5.73 & 20.3 & 5.39 & 19.1 \\
\hline LT & 10.97 & 50.9 & 5.72 & 26.5 & 4.52 & 21.0 \\
\hline LV & 11.62 & 53.2 & 5.61 & 25.7 & 3.65 & 16.7 \\
\hline PL & 17.11 & 59.3 & 5.93 & 20.6 & 4.50 & 15.6 \\
\hline RO & 9.77 & 49.9 & 3.85 & 19.7 & 3.97 & 20.3 \\
\hline SL & 16.73 & 55.8 & 6.31 & 21.1 & 6.33 & 21.2 \\
\hline SK & 13.38 & 56.8 & 3.71 & 15.7 & 5.50 & 23.3 \\
\hline
\end{tabular}

Source: Author's calculations.

Following the endogenous growth theory the expenditure on education are growth supporting (the highest ratios are seen for the Baltic states and Portugal). The expenditure on health represent a significant portion of WSE in the Ireland, the Czech Republic and Slovakia with Portugal, Poland and the Netherlands lagging behind.

From Table 2 one can deduce that not only the ratio of WSE on GDP, but also the composition of this aggregate is relevant.

\section{Partial Approach - Simple Correlations with Mean Values}

The relationship of economic growth and the level and composition of government expenditure has been investigated for many years (Hindriks and Myles, 2006 and many others). One of the often discussed questions is the direction of causality (Bleaney, Gemmell, Kneller, 2001; Afonso, Allegre, 2008).

Keynesian propositions treat government expenditure as an exogenous factor, as the right-hand side variable and GDP growth as the left-hand side variable in the growth regressions. On the other side, government expenditure can be seen as being 
determined by the preferences of the population as expressed through the political system. Wagner's law (Brown, Jackson, 1994) implies that government expenditure can be treated as an endogenous factor relating government expenditure to GDP via the income elasticity of demand for government provided goods and services.

The direction of causality can be settled in a dynamic setting only. In what follows we correlate WSE and GDP growth rate taking into account that in addition to the autoregressive behaviour of economic growth the expenditure items induce an impact on growth distributed across several years (Afonso, Allegre, 2008).

Due to the data limitations, especially for EU-10 (see time periods in Table 2), we account for the longer-term relationship by using of variables expressed in larger frequency periods (Masson, 2000). Four spending items serving as a proxy for the extent of the welfare state (WSE) are the mean values for 2002-6 and sub-periods 2002-4. 2004-6, respectively and the subsequent growth rates of GDP are the mean values for 2006-8 assuming the causality runs from WSE to GDP growth rate. This selection of the periods is dictated by the data availability which does not allow to take into account a longer period.

Figure 1 indicates the negative association between the mean values for WSE and the subsequent GDP growth rate for our sample dataset. Estimated correlations of WSE and subsequent GDP growth rate are summarized in Table 4.

Table 4

Correlation Matrices for Mean Values (WSE 2002-6, GDP growth rate 2006-8)

\begin{tabular}{|l|c|}
\hline & welfare state expenditure \\
\hline EU-25 GDP growth rate & -0.6588 \\
\hline EU-15 GDP growth rate & -0.3516 \\
\hline EU-10 GDP growth rate & -0.6267 \\
\hline
\end{tabular}

Source: Authors Calculations

Figure 1

WSE and GDP Growth Rate, EU-25 (mean values of WSE 2002-6 and GDP growth rate 2006-8)

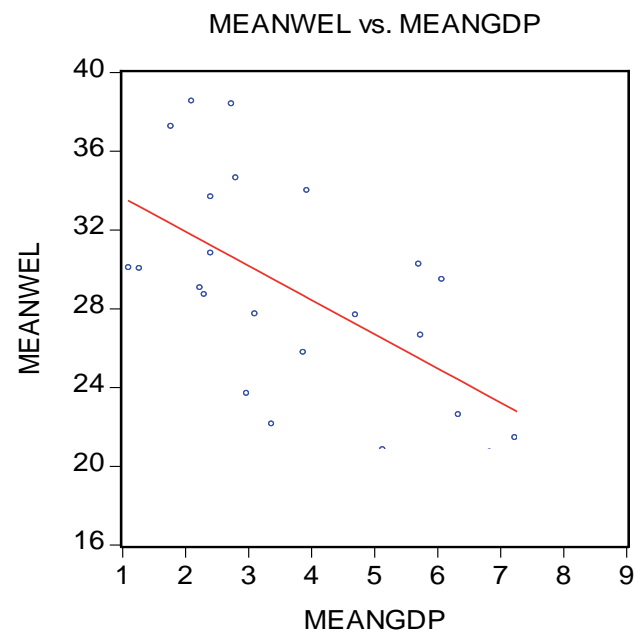


Negative correlation is smaller for EU-15 and much higher for EU-10. If we divide the period 2002-2006 into two parts, then for EU-25 for WSE in 2002-4 the impact on the growth rates in 2006-8 gives the negative correlation -0.6267. WSE in 2004-6 hence influenced the in Table 3 mentioned GDP growth rate with a higher negative correlation -0.6954 .

Table 4 depicts the aggregate impact of WSE. Having disentangled the internal composition of the WSE we calculate in a similar way correlations for the three main items: social protection (spr), education (edu) and health (hea) - see Table 5.

Table 5

Correlation Coefficients for Mean Values (expenditure on social protection, education and health 2002-6, GDP growth rate 2006-8)

\begin{tabular}{|l|c|c|c|}
\hline & Social protection & Education & Health \\
\hline EU-25 GDP growth rate & -0.5800 & -0.3611 & -0.6962 \\
\hline EU-15 GDP growth rate & -0.1417 & -0.4304 & -0.6051 \\
\hline EU-10 GDP growth rate & -0.4175 & -0.5882 & -0.3869 \\
\hline
\end{tabular}

More detailed information in Table 5 shows, maybe rather surprisingly, also the negative correlation between expenditure on education and the growth rate for all our samples.

Among the EU-10 a closer look reveals the differences between the "central" post-socialist countries (the Czech Republic, Hungary, Poland, Slovakia and Slovenia) and the "peripheral" countries (Bulgaria, Estonia, Latvia, Lituania and Romania). In the latter group the differences between the mean values of the WSE and GDP growth rate are higher confirming the development theory.

Table 6

Central and Peripheral Postsocialist EU Countries (mean of the WSE 2002-6 and mean GDP growth rate 2006-8)

\begin{tabular}{|l|c|c|}
\hline Central countries & GDPmeans & WSEmeans \\
\hline CZ & 5.73 & 26.66 \\
\hline HU & 2.30 & 28.72 \\
\hline PL & 6.07 & 29.48 \\
\hline SL & 5.70 & 30.26 \\
\hline SK & 8.63 & 23.36 \\
\hline unweighted average & 5.69 & 27.70 \\
\hline peripheral countries & \multicolumn{2}{|}{} \\
\hline BG & 6.33 & 22.62 \\
\hline EE & 5.13 & 20.84 \\
\hline LT & 6.83 & 20.72 \\
\hline LV & 7.23 & 21.46 \\
\hline RO & 7.57 & 19.52 \\
\hline unweighted average & 6.62 & 21.03 \\
\hline
\end{tabular}


Lower growth rates and higher WSE distinguish "central" post-socialist EU countries from their "peripheral" counterparts, which are catching up on the EU average more quickly. Last but not least, we must be aware that the results of the partial approach are with a grain of salt.

\section{Government Budget Constraint - Expenditure and Taxes}

In his original article Helms (1985) stresses that neither expenditure nor taxes cannot be studied in isolation. To sort out the countervailing effects of expenditure and taxes one must explicitly recognize the government budget constraint. His results indicate that state and local tax increases significantly retard growth when the revenue is used to fund transfer payments. However, when the revenue is used instead to finance improved public services the favourable impact may more than counterbalance the disincentive effects of the associated taxes.

With a comprehensive accounting, Mofidi and Stone (1990) demonstrate that state and local taxes and expenditures form (at least a near) budget identity, implying (at least nearly) perfect multicollinearity. Therefore, some component must be omitted to obtain precise estimates of coefficients of the remaining components. They follow Helms in omitting transfer-payment expenditures, so that "estimated coefficients on the tax and other expenditure variables represent the effect of increasing that variable through an exactly offsetting change in transfer payment expenditures" (Mofidi, Stone, 1990, p. 687).

A key feature of this approach is to recognize that the sum of the uses must identically equal the sum of sources; both the sources and the use sof funds must be considered. The point can be put formally (see Kneller, Bleaney, Gemell, 1999, pp. 174-175 and Bleaney, Gemell, Kneller, 2001, pp.39-40).

The rate of growth of real GDP, $g_{t}$ in country $i$ at time $t$ is a function of control variables, $Y_{\mathrm{it}}$, and a vector of fiscal variables, $\mathrm{X}_{\mathrm{jt}}$ :

$$
\mathrm{g}_{\mathrm{it}}=\alpha \sum_{i=1}^{k} \beta_{\mathrm{i}} \mathrm{Y}_{\mathrm{it}}+\sum_{j=1}^{m} \delta_{\mathrm{j}} \mathrm{X}_{\mathrm{jt}}+\mathrm{u}_{\mathrm{it}}
$$

Assuming that all elements of the budget (including the budget balance) are included, so that

$$
\sum_{j=1}^{m} X_{j t}=0
$$

One element of $X$ must be omitted in the estimation of equation (1) in order to avoid perfect collinearity. The omitted variable is effectively the assumed compensating element within the government's budget constraint. ${ }^{1}$ Thus, if we rewrite equation (1) as:

$$
\mathrm{g}_{\mathrm{it}}=\alpha+\sum_{i=1}^{k} \beta_{\mathrm{i}} \mathrm{Y}_{\mathrm{it}}+\sum_{i=1}^{m-1} \delta_{\mathrm{j}} \mathrm{X}_{\mathrm{jt}}+\delta_{\mathrm{m}} \mathrm{X}_{\mathrm{mt}}+\mathrm{u}_{\mathrm{it}}
$$
and then omit $X_{\mathrm{mt}}$ to avoid multicollinearity, the identity $\sum_{j=1}^{m} \mathrm{X}_{\mathrm{jt}}=0$ implies that the
equation actually being estimated is :

1 The authors try to discriminate between the neoclassical growth model (Solow) and endogenous growth models (Barro, Lucas) by analysing the impact of various sub-divisions of expenditures (productive and nonproductive) and taxes (distortionary, nondistortionary) on economic growth. 


$$
\mathrm{g}_{\mathrm{it}}=\alpha+\sum_{i=1}^{k} \beta_{\mathrm{i}} \mathrm{Y}_{\mathrm{it}}+\sum_{j=1}^{m=1}\left(\delta_{\mathrm{j}}-\delta_{\mathrm{m}}\right) \mathrm{X}_{\mathrm{jt}}+\mathrm{u}_{\mathrm{it}}
$$

The standard hypothesis test of a zero coefficient of $X_{\mathrm{jt}}$ is in fact testing the null hypothesis that $\left(\delta_{\mathrm{j}}-\delta_{\mathrm{m}}\right)=0$ rather than $\delta_{\mathrm{j}}=0$. It follows that the correct interpretation of the coefficient on each fiscal item is as the effect of a unit change in the relevant item offset by a unit change in the omitted category (see Equation 3), which is the implicit financing element. In this way not only WSE are estimated but also their financing is taken into account. If the category chosen to be omitted is altered, the estimated coefficients of the included items will change.

\section{a) current-period effects}

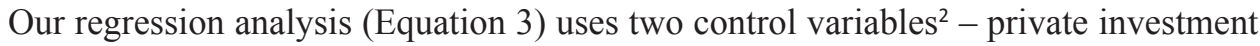
as a ratio to GDP in current prices and labour force growth (other possibilities see the literature review). Taxes are simply disaggregated into distortionary (direct taxes plus social security contributions received), indirect taxes (taxes linked to imports and production) and other taxes and fees (the difference between total revenue and two enumerated kinds of taxes). On the other side of the budget, on the expenditure side, total expenditure is composed of WSE and other expenditure.

Table7

Current-Period Effects (EU-25)

\begin{tabular}{|l|c|c|c|}
\hline Estimation technique: & OLS & Fixed effects & Random effects \\
\hline Dependent variable: GDP growth rate \\
\hline Omitted fiscal variable: distortionary taxes \\
\hline private investment & 0.039 & 0.056 & 0.06 \\
& $(8.47)$ & $(1.18)$ & $(1.40)$ \\
\hline labour force growth & 0.039 & 0.065 & 0.09 \\
& $(0.44)$ & $(0.79)$ & $(0.95)$ \\
\hline indirect taxes & 0.432 & -0.017 & 0.20 \\
& $(5.53)$ & $(-0.15)$ & $(1.81)$ \\
\hline other taxes and fees & 0.269 & -0.159 & 0.22 \\
& $(2.90)$ & $(-1.11)$ & $(1.85)$ \\
\hline welfare state expenditure & -0.233 & -0.106 & -0.28 \\
& $(-8.17)$ & $(-1.32)$ & $(-6.96)$ \\
\hline other expenditure & -0.081 & 0.097 & -0.13 \\
& $(-1.46)$ & $(1.17)$ & $(-1.86)$ \\
\hline public balance & 0.129 & 0.265 & 0.13 \\
& $(2.35)$ & $(3.41)$ & $(1.99)$ \\
\hline $\mathbf{R}_{\text {adj }}{ }^{2}$ & 0.36 & 0.64 & 0.26 \\
\hline
\end{tabular}

Note: Number of observations 289. Figures in parenthesis are t-statistics. Both redundant fixed effects test and Hausman test prefer fixed effects with $\mathrm{P}=0.00$.

2 The number of control variables could of course be increased by adding other items but the impact of different controls is not in the centre of our research. We prefer using private investment to avoid collinearity with government expenditure. All variables in this paper are from Eurostat 's AMECO and COFOG datasets. 
First of all we examine current-period effects neglecting the time lags between WSE and the GDP growth rate.

As the implicit financing element we use distortionary taxes, but the use of remaining taxes does not lead to different results vis-à-vis WSE. The signs of variables are consistent with theory, but mainly statistically insignificant especially in the column devoted to fixed effects.

The public balance has a large and statistically significant coefficients in all three cases (a notable feature of the previous research in this field).

\section{b) lagged effects}

According to theory the relationship of fiscal variables to growth is dynamic by nature and the dynamics can therefore not be omitted. In what follows we regress two-year, three-year, four-year and five-year forward looking moving average of GDP growth on yearly expressed tax and expenditure variables to capture the dynamics and to refrain from endogeneity.

Table 8

\section{Lagged Effects}

\begin{tabular}{|l|c|c|c|c|c|c|c|c|}
\hline \multicolumn{7}{|l|}{ Estimation technique: Pooled EGLS (cross-section weights) } \\
\hline Dependent variable: 2-3- 4-and 5year forward moving average of the GDP growth rate \\
\hline Omitted variable: & \multicolumn{7}{|c|}{ distortionary taxes } \\
\hline & $\mathbf{a}$ & $\mathbf{b}$ & $\mathbf{C}$ & $\mathbf{d}$ & $\mathbf{3}$ & $\mathbf{f}$ & $\mathbf{g}$ & $\mathbf{h}$ \\
\hline private investment & 0.1867 & 0.1565 & 0.1788 & 0.1717 & 0.1872 & 0.1587 & 0.1833 & 0.1788 \\
& $(5.34)$ & $(4.96)$ & $(6.51)$ & $(5.42)$ & $(5.30)$ & $(4.95)$ & $(6.65)$ & $(5.64)$ \\
\hline labour force growth & 0.01 & 0.1348 & 0.1555 & 0.0753 & 0.0159 & 0.1412 & 0.1525 & 0.0633 \\
& $(0.21)$ & $(3.23)$ & $(3.65)$ & $(1.56)$ & $(0.32)$ & $(3.35)$ & $(3.56)$ & $(1.30)$ \\
\hline distortionary taxes & ----- & ------ & ------ & ----- & -0.1479 & -0.1644 & -0.1829 & -0.2449 \\
& $(-2.16)$ & $(-2.60)$ & $(-3.58)$ & $(-4.59)$ & & & & \\
\hline indirect taxes & -0.1620 & -0.2324 & -0.3308 & -0.3364 & -0.3132 & -0.4053 & -0.5136 & -0.5803 \\
& $(-1.90)$ & $(-2.62)$ & $(-4.02)$ & $(-3.87)$ & $(-3.16)$ & $(-3.96)$ & $(-5.69)$ & $(-6.15)$ \\
\hline other taxes and fees & -0.1946 & -0.2157 & -0.1364 & -0.0062 & -0.3293 & -0.3694 & -0.2989 & -0.2059 \\
& $(-1.78)$ & $(-2.36)$ & $(-1.98)$ & $(-0.10)$ & $(-3.09)$ & $(-4.10)$ & $(-4.20)$ & $(-3.18)$ \\
\hline welfare state exp. & -0.1834 & -0.2030 & -0.2030 & -0.2451 & ------ & ------ & ------ & ------- \\
& $(-3.79)$ & $(-3.30)$ & $(-4.07)$ & $(-4.85)$ & ----- & ----- & ----- & ------ \\
\hline other expenditure & 0.1111 & 0.1661 & 0.1788 & 0.050 & 0.2679 & 0.3390 & 0.3614 & 0.2867 \\
& $(1.80)$ & $(3.12)$ & $(3.89)$ & $(1.12)$ & $(3.87)$ & $(5.20)$ & $(6.63)$ & $(5.51)$ \\
\hline public balance & 0.2735 & 0.2635 & 0.2040 & 0.058 & 0.4405 & 0.4469 & 0.3969 & 0.3021 \\
& $(4.60)$ & $(5.07)$ & $(4.70)$ & $(1.41)$ & $(8.82)$ & $(9.98)$ & $(10.78)$ & $(8.34)$ \\
\hline $\mathbf{R}^{2}$ adj & 0.81 & 0.87 & 0.92 & 0.90 & 0.81 & 0.87 & 0.92 & 0.90 \\
\hline
\end{tabular}

Note: ad a) and ad e) 2-year forward moving average (270 observations); ad b) and ad f) 3-year forward moving average (251 observations); ad c) and ad g) 4-year forward moving average (232 observations); ad d) and ad h) 5-year forward moving average (213 observations). t-statistics in parentheses. 
Some authors, e.g. Devarajan et al., (1996), Kneller et al. (1999) and Folster, Henrekson (2001) use averages over the five-year period to eliminate short-term fluctuations. Kneller et al. test the robustness by shifting the 5-year periods. Bleaney et al. (2001) allow the data to determine the appropriate number of lags (more than five years).

The forward lags in our investigation is chosen to reflect the fact that public expenditures often take time before their effects on the economic growth can be registered. To enable comparison of both current-period and lagged effects we have not changed in Table 8 the omitted variable as the implicit financing element and add another omitted variable WSE but lagged the dependent variable by using forward moving average of the GDP growth rate.

The signs of variables, when we omit distortionary taxes, are consistent with theory and are mainly statistically significant. In columns a, b, c, d estimated coefficients represent the effect of an increase in a given fiscal variable that arises from an offsetting change in distortionary taxes. The coefficient of WSE says that an increase by one percentage point decreases the GDP growth rate by 0.20 percentage points. These results appear to be robust across different time lags. The other expenditure (the remaining 6 items of COFOG classification) has expected positive sign, partially statistically significant.

From the table we can calculate also the net impacts (Helms, 1985) as the algebraic sum of the tax and expenditure coefficients. E. $g$. when WSE is the omitted variable we can calculate the net effect of other expenditure financed by distortionary taxes. The net effect on the growth rate of GDP is positive in columns e $(0.12), \mathrm{f}(0.1746)$, $\mathrm{g}(0.1785)$, and $\mathrm{h}(0.0418)$. But when other expenditure is financed by indirect taxes the net effect is negative.

The explanatory power of the equations is relatively high, judging by the values of the adjusted coefficient of determination. This is mainly due to the homogenity of the EU countries in the pool.

The partial conclusion which can be drawn is that lagged effects are more negative vis-à-vis economic growth than current-period effects. This result is not at variance with mainstream theory. Last, but not least, disentangling WSE, we obtain Table 9. 
Table 9

Lagged Effects - Desintangling WSE

\begin{tabular}{|c|c|c|c|c|}
\hline \multicolumn{5}{|c|}{ Estimation technique: Pooled EGLS (cross-section weights) } \\
\hline \multicolumn{5}{|c|}{ Dependent variable: 2-, 3-, 4- and 5 year forward moving average of the GDP growth rate } \\
\hline \multicolumn{5}{|c|}{ Omitted variable: distortionary taxes } \\
\hline & a & b & c & d \\
\hline private investment & $\begin{array}{l}0.1662 \\
(5.22)\end{array}$ & $\begin{array}{l}0.1621 \\
(5.04)\end{array}$ & $\begin{array}{l}0.1669 \\
(5.81)\end{array}$ & $\begin{array}{l}0.1667 \\
(5.11)\end{array}$ \\
\hline labour force growth & $\begin{array}{l}-0.0058 \\
(-0.12)\end{array}$ & $\begin{array}{l}0.0990 \\
(2.36) \\
\end{array}$ & $\begin{array}{l}0.1137 \\
(2.72)\end{array}$ & $\begin{array}{l}0.0462 \\
(0.99)\end{array}$ \\
\hline indirect taxes & $\begin{array}{l}-0.1770 \\
(-2.29)\end{array}$ & $\begin{array}{l}-0.2163 \\
(-2.67)\end{array}$ & $\begin{array}{l}-0.2610 \\
(-3.49)\end{array}$ & $\begin{array}{l}-0.2323 \\
(-2.70)\end{array}$ \\
\hline other taxes and fees & $\begin{array}{l}-0.1903 \\
(-1.88)\end{array}$ & $\begin{array}{l}-0.2369 \\
(-2.81)\end{array}$ & $\begin{array}{l}-0.1587 \\
(-2.42)\end{array}$ & $\begin{array}{l}-0.0414 \\
(-0.63)\end{array}$ \\
\hline social protection & $\begin{array}{l}-0.3685 \\
(-4.69)\end{array}$ & $\begin{array}{l}-0.4519 \\
(-6.55)\end{array}$ & $\begin{array}{l}-0.4305 \\
(-7.64)\end{array}$ & $\begin{array}{l}-0.4456 \\
(-7.39)\end{array}$ \\
\hline education & $\begin{array}{l}0.1701 \\
(0.86)\end{array}$ & $\begin{array}{l}0.3580 \\
(2.37)\end{array}$ & $\begin{array}{l}0.3628 \\
(2.66)\end{array}$ & $\begin{array}{l}0.2610 \\
(1.67)\end{array}$ \\
\hline health & $\begin{array}{l}-0.0926 \\
(-0.87)\end{array}$ & $\begin{array}{l}-0.1316 \\
(-1.26)\end{array}$ & $\begin{array}{l}-0.2320 \\
(-2.51)\end{array}$ & $\begin{array}{l}-0.2111 \\
(-2.00)\end{array}$ \\
\hline other expenditure & $\begin{array}{l}0.1105 \\
(1.75)\end{array}$ & $\begin{array}{l}0.1658 \\
(3.09) \\
\end{array}$ & $\begin{array}{l}0.1460 \\
(3.27)\end{array}$ & $\begin{array}{l}0.0680 \\
(1.44)\end{array}$ \\
\hline public balance & $\begin{array}{l}0.2667 \\
(4.90)\end{array}$ & $\begin{array}{l}0.2561 \\
(5.63)\end{array}$ & $\begin{array}{l}0.1987 \\
(5.15)\end{array}$ & $\begin{array}{l}0.0842 \\
(1.95)\end{array}$ \\
\hline $\mathbf{R}_{\text {adj }}^{2}$ & 0.83 & 0.89 & 0.92 & 0.92 \\
\hline
\end{tabular}

Note: t-statistics in parenthesis.

Looking at the table we see the high negative coefficients for the main item of WSE - social protection. The coefficients are very high and statistically significant in all lagged regressions displaying the robustness of the conclusion: The fiscal variable social protection financed by distortionary taxes (the implicit financing element) is the most important factor negatively influencing the rate of growth of GDP (at least in our sample). Education has a positive sign improving therefore economic growth, whereas health exhibits a negative, mainly insignicative, sign.

\section{Conclusions and Caveats}

The descriptive analysis of WSE shows that since 1995 (the starting point of our regressions) their ratio to GDP has been decreasing till 2007 with a sharp increase in 2008. The partial approach - simple correlations with means values (WSE for 2002-6 and the subsequent growth rate of GDP for 2006-8) figures the negative association. Negative correlation is smaller for old EU countries (EU-15) and higher 
for post-socialist EU countries (EU-10). Among the EU-10 a closer look reveals the higher differences between the mean values of WSE and GDP growth rate for the "peripheral" than for "central" countries.

Following the original article of Helms (1985) to sort out the countervailing effects of expenditure and taxes one must explicitly recognize the government budget constraint. In analysing current-period effects both redundant fixed effects test and Hausman test prefer fixed effects which we apply in this paper. As the implicit financing element (omitted variable) we use distortionary taxes, but the use of remaining tax items does not lead to different results vis-à-vis WSE. The signs of variables are consistent with theory, but mainly statistically insignificant.

According to theory the relationship of fiscal variables to growth is dynamic by nature and the dynamics can therefore not be omitted. We regress 2-year, 3-year, 4-year and 5-year forward looking moving average of GDP growth on yearly expressed tax and expenditure variables to capture the dynamics and to restrain from endogeneity. Omitted variables are both distortionary taxes and WSE. The coefficient of WSE says that an increase by one percentage point decreases GDP growth rate by 0.20 percentage points when we omit distortionary taxes. These results appear to be robust across different time lags. The other expenditure (the remaining 6 items of COFOG classification) has expected positive sign, partially statistically significant. We calculate the net impacts as the algebraic sum of the tax and expenditure coefficients. When WSE is the omitted variable we can calculate, $e . g$., the net effect of other expenditure financed by distortionary taxes. The net effect on the growth rate is positive for all lags. But when other expenditure is financed by indirect taxes the net effect is negative. Lagged effects of fiscal items are more negative vis-a-vis economic growth than current-period effects.

The main conclusion is that WSE reduces growth whereas other expenditure supports growth. All tax items (distortionary, indirect and other taxes and fees) have negative impacts on economic growth.

Theoretically there are several channels through which government expenditure can impact economic growth. The composition, efficiency and effectiveness of expenditure is one of the five dimensions of the quality of public finance. A set of indicators has been identified for each of the five dimensions. Composite indicators (Public Finances in EMU, 2009) try to measure (as benchmarks the authors used the unweighted EU-15 average) the quality of public finance.

Tables in Public Finances in EMU, 2009 show the positions of Member States. As concerns composite indicators the tables (pp. 77, 78) reveal (data from 2007) that no country outperformed in all dimensions, but some countries showed weaknesses in a number of areas. The post-socialist, recently acceded EU members get high scores in the composition of expenditure (the majority of them over the EU average), however, this is not yet fully reflected in outcomes (especially health).

Government expenditure analysed in our paper does not yet mean the efficiency in spending. Assessing efficiency can serve as a benchmark to guide expenditure rationalization by focusing cuts in relatively inefficient areas of spending.

According to some authors (e.g. Afonso, Schuknecht, Tanzi, 2006) countries with lean public sectors and public expenditure ratios not far from 30 percent of GDP tend to be most efficient. They stress that calls to allocate a given, or a larger share of 
national budgets to health and education assume the identity between expenditure and benefits, but the two can be widely different and this difference is central to the concept of efficiency. The same conclusion has been drawn in a newer paper of these authors (2006) applying public sector performance (PSP) and public sector efficiency (PSE) scores.

The message is clear: especially post-socialist new EU Member States can considerably increase the efficiency of government expenditure on the welfare state by improving the outcomes and restraining the spending taking into account a negative association between this kind of expenditure and economic growth.

\section{Appendix}

\section{Definition of Initial Variables}

\begin{tabular}{|l|c|c|}
\hline GDP at current market prices, national currency & UVGD & Ameco \\
\hline GDP at constant (2000) market prices (rate of growth) & OVGD & Ameco \\
\hline $\begin{array}{l}\text { Gross fixed capital formation at current prices; private sector } \\
\text { (ratio to GDP at current prices) }\end{array}$ & UIGP & Ameco \\
\hline Total labour force (rate of growths) & NLTN & Ameco \\
\hline $\begin{array}{l}\text { Current taxes on income and wealth (direct taxes); general } \\
\text { government }\end{array}$ & UTYG & Ameco \\
\hline $\begin{array}{l}\text { Taxes linked to imports and production (indirect taxes); general } \\
\text { government }\end{array}$ & UTVG & Ameco \\
\hline Actual social contributions received; general government & UTAG & Ameco \\
\hline Total revenue; general government & URTG & Ameco \\
\hline Total expenditure; general government & UUTG & Ameco \\
\hline Net lending (+) or net borrowing (-); general government & UBLG & Ameco \\
\hline Social protection & GF.10 & COFOG \\
\hline Health & GF.07 & COFOG \\
\hline Education & GF.09 & COFOG \\
\hline Housing and community amenities & GF.06 & COFOG \\
\hline
\end{tabular}

Data source: European Commission (EUROSTAT). All fiscal variables are ratios to GDP.

\section{Definition of Derived Variables}

Distortionary taxes $=$ direct taxes + actual social contribution received

Other taxes and fees $=$ total revenue - (distortionary taxes + indirect taxes)

Welfare state expenditure $=$ social protection + health + education + housing and com. amenities

Other expenditure $=$ total expenditure - welfare state expenditure 


\section{References}

Afonso, A.; Allegre, J. G. (2008), "Economic Growth and Budgetary Components: A Panel Assessment for the EU.” European Central Bank, WP, No. 848, January 2008.

Afonso, A.; Furceri, D. (2008), "Government Size, Composition, Volatility and Economic Growth." European Central Bank, WP, No. 849, January 2008.

Afonso, A.; Schuknecht, L.; Tanzi, V. (2003), "Public Sector Efficiency: An International Comparison." European Central Bank, WP, No. 242, July 2003.

Afonso, A.; Schuknecht, L.; Tanzi, V. (2006), "Public Sector Efficiency: Evidence for New EU Member States and Emerging Markets." European Central Bank, WP, No. 581, January 2006.

Akitoby, B.; Clements, B.; Gupta, S.; Inchauste, G. (2004), "The Cyclical and Long-Term Behavior of Government Expenditure in Developing Countries.” IMF Working Paper, WP/04/202, October 2004.

Arpaia, A.; Turrini, A. (2008), "Government Expenditure and Economic Growth in the EU: Long-Run Tendencies and Short-Run Adjustment." EC, European Economy, Economic Papers 300, February 2008.

Barr, N. (2004), Economics of the Welfare State. Oxford University Press, 2004.

Bleaney, M.; Gemell, N.; Kneller, R. (2001), "Testing the Endogenous Growth Model: Public Expenditure, Taxation, and Growth over the Long Run." Canadian Journal of Economics, No. 1, February 2001.

Brown, C. V.; Jackson, P. M. (1994), Public Sector Economics. Oxford, UK: Blackwell, 1994.

Clements, B.; Faircloth, C.; Verhoeven, M. (2007), "Public Expenditure in Latin America: Trends and Key Policy Issues." IMF, WP/07/21, February 2007.

Easterly, W.; Rebelo, S. (1993), "Fiscal Policy and Economic Growth. An Empirical Investigation." Journal of Monetary Economics. 1993, Vol. 32, pp. 417-458.

Eurostat (1995), ESA 95. European System of National and Regional Accounts, at http://circa.europa. eu/irc/dsis/nfaccount/info/data/ESA95/en/titelen.htm.

Eurostat (2005), General Government Expenditure by Function in the 2003. EC, Eurostat, Statistics in Focus, Economy and Finance, 28/2005.

Eurostat (2007), Manual on Sources and Methods for the Compilation of COFOG Statistics. EC, Eurostat, 2007.

Eurostat (2000-2009), European Economy - Public Finances in EMU. Eurostat annual reports, 2000-2009.

Folster, S.; Henrekson, M. (2000), "Growth Effects of Government Expenditure and Taxation in Rich Countries.” European Economic Review. 2001, Vol. 45, pp. 1501-1520.

Furceri, D.; Ribeiro, M. P. (2008), "Government Spending Volatility and the Size of Nations.” European Central Bank, WP No. 924, August 2008.

Gerson, P. (1998), "The Impact of Fiscal Policy Variables on Output Growth.” IMF, WP/98/1, January 1998.

Hauner, D.; Kyobe, A. (2008), "Determinants of Government Efficiency." IMF, WP/08/228, September 2008.

Helms, L. (1985), "The Effect of State and Local Taxes on Economic Growth: A Time Series-Cross Section Approach." The Review of Economics and Statistics. November 1985, Vol. 67, No. 4, pp. 574-582.

Hindriks, J.; Myles, G. D. (2006), Intermediate Public Economics. Cambridge, Massachusetts, London, UK: The Mit Press, 2006.

Kneller, R.; Bleaney, M.; Gemell, N. (1999), "Fiscal Policy and Growth: Evidence from OECD Countries." Journal of Public Economics, 1999, Vol. 74, pp. 171-190.

Kocherlakota, N.; Yi, K. M. (1997), “Is There Endogenous Long-Run Growth?” Evidence from the US and the UK. Journal of Money, Credit and Banking. 1997, Vol. 29, No. 2, pp. 235-262. 
Masson, P. (2000), "Fiscal Policy and Growth in the Context of European Integration." IMF, WP/00/133, July 2000.

Mattini, T.; Gunnarsson, V. (2007), "Budget Rigidity and Expenditure Efficiency in Slovenia." IMF, WP/07/131, June 2007.

Mofidi, A.; Stone, J. (1990), "Do State and Local Taxes Affect Economic Growth?" The Review of Economics and Statistics, May 1990, Vol. 72, No. 4, pp. 686-681.

Odedokun, M. O. (2001), "Public Finance and Economic Growth." WIDER, Discussion Paper No. 2001/72.

Razin, A.; Sadka, E.; Chang, W. N. (2005), The Decline of the Welfare State, Demography and Globalization. Cambridge, Massachusetts; London, UK: The MIT Press, CESifo Book Series, 2005. ISBN 0-262-18244-0.

Tanzi, V.; Schuknecht, L. (1997), "Reconsidering the Fiscal Role of Government: The International Perspective." American Economic Review, May 1997, Vol. 87, No. 2, pp. 164-168. 